\title{
THE ELEMENTS OF FLUID MECHANICS OF BILE FLOW THROUGH BILIARY DRAINAGE CATHETERS
}

\section{Wenguang Li}

School of Energy and Power Engineering, Lanzhou University of Technology

liwg40@sina.com

DOI: 10.17489/biohun/2019/1/03

\begin{abstract}
Obstructive jaundice in the biliary tract can infect blood and result in mortality with a high rate. Percutaneous transhepatic biliary drainage (PTBD) with catheters is a useful solution discharging the obstructive jaundice. However, the elements of fluid mechanics showing clinical performance of a PTBD catheter have been documented little so far. In the article, empirical relationships between bile flow rate and pressure gradient in PTBD catheters were studied in terms of equivalent friction factor for the first time. Firstly, an equivalent friction factor in a catheter was raised and determined based on existing in vitro experimental data of bile flow through the catheters with different materials, various inner diameters and lengths under various pressure differences. Then, an empirical correlation of bile flow rate through a catheter was established based on pressure gradient, inner diameter and bile viscosity. The correlation was used to identify effects of catheter inner diameter and bile viscosity on the bile flow rate under the physiological bile pressure difference across obstructed common bile ducts. The feature of minor hydraulic losses in the catheters was clarified, too. The proposed equivalent friction factor was proportional to Reynolds number in a power of -0.654 in comparison with a power of -1 for the fully developed laminar flow in circular pipes. The bile flow rate through a catheter was proportional to inner diameter, kinematic viscosity, and pressure gradient in the powers of $3.2,-0.5$ and 0.74 , respectively. The minor hydraulic losses could be significant when Reynolds number was greater than 100 .
\end{abstract}

Keywords: percutaneous transhepatic biliary drainage; biliary drainage catheter; bile; flow rate; friction factor; Reynolds number

\section{Introduction}

Obstructive jaundice is a special situation of jaundice when the bile is stopped flowing into the duodenum and remains in the blood due to gallstones in the common bile duct or extrinsic compression by tumours external to the common bile duct. The obstructive jaundice is a serious condition associated with high mortality rates and should be treated instantly by using percutaneous transhepatic biliary drainage (PTBD). PTBD is a procedure based on which the blocked bile is discharged into a drainage bag outside of the human body (external drainage in Figure 1a) or the duodenum through the common bile duct (internal drainage in Figure $1 b$ ) by using a catheter. ${ }^{1,2}$ The internal drainage, the bile can flow in the internal catheter or flow into the bag thorough the external drainage catheter, depending on the resistance in the two catheters.

Even though PTBD is palliative, but it can improve quality of life for patients with benign and malignant biliary diseases with success rates of 82-99 \%. ${ }^{3-11}$ PTBD has been become an effective method for relief of biliary obstruction associated 

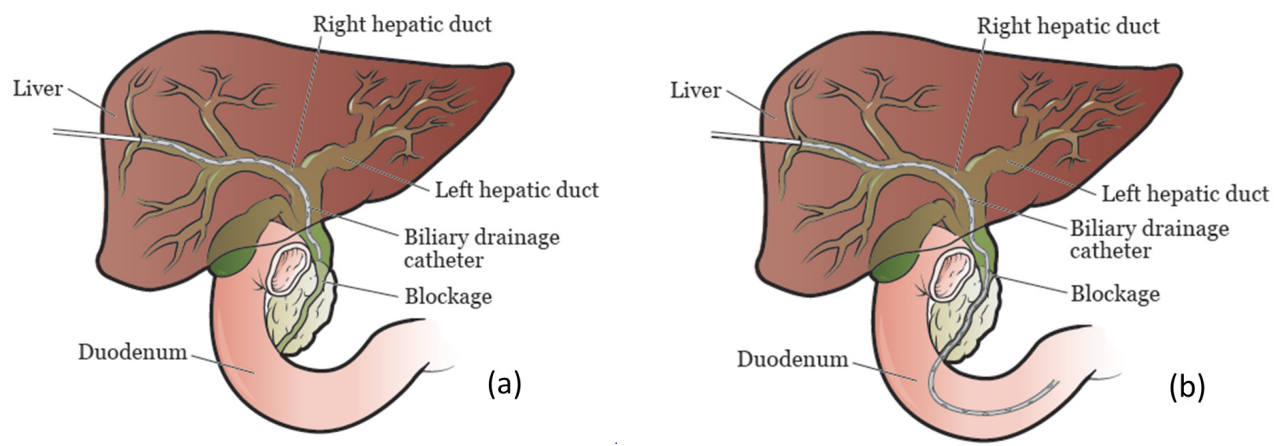

Figure 1. The external (a) and internal (b) percutaneous transhepatic biliary drainage, the pictures are from https://www.mskcc.org/cancer-care/patient-education/about-your-biliary-drainage-catheter

with both benign and malignant conditions.

Even though PTBD in patients is replaced every 4 or 6 weeks, unfortunately, PTBD is subject to complications after patients with malignant biliary disease undergo placement of drainage catheter. ${ }^{6-8,10,12,13}$ The complications can be cholangitis, catheter dislodgement, leaking around catheter, obstructed catheter, hemobilia, hypersecretion of bile, biliopleural fistula, bile duct perforation and pneumothorax ${ }^{14}$, their occurrence percentages in 179 patients are illustrated in Figure 2. The total percentage of the complications related to catheter is as high as $43 \%$. This means that the catheter performance plays a vitally important role in PTBD technique.

The catheter dislodgement and leaking complications connect with catheter design and soft tissue bimechanical property, while the catheter obstruction is associated with catheter design and bile fluid mechanics inside. Even though the catheter obstruction has made a $12.3 \%$ contribution to the total complication occurrence, it can cause catheter malfunction

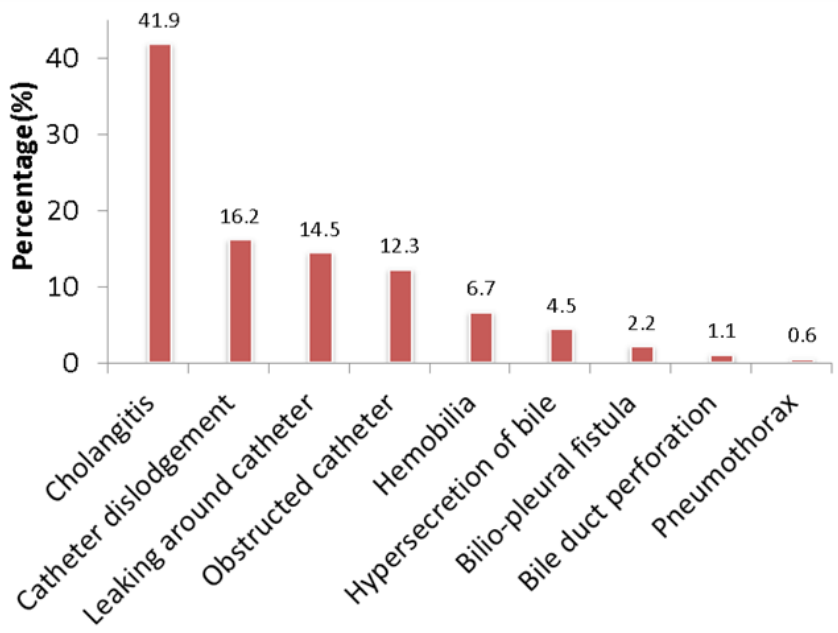

Figure 2. The percentages of complications after PTBD occurred in 179 patients with malignant biliary obstruction, the percentages were recalculated based on the data in the table in ${ }^{14}$ 


\begin{tabular}{|c|c|c|c|c|c|c|c|}
\hline \multirow[t]{2}{*}{ Material } & \multirow[t]{2}{*}{$\underset{\text { (French) }}{\mathrm{D}}$} & \multirow[t]{2}{*}{$\underset{(\mathrm{mm})}{\mathrm{d}}$} & \multirow[t]{2}{*}{$\begin{array}{c}\mathrm{L} \\
(\mathrm{cm})\end{array}$} & \multicolumn{4}{|c|}{$\begin{array}{l}\text { Flow rate } \mathrm{Q}(\mathrm{ml} / \mathrm{s}) \text { under a } \\
\text { pressure difference }\left(\mathrm{cmH}_{2} \mathrm{O}\right)\end{array}$} \\
\hline & & & & 1 & 2 & 6 & 9 \\
\hline \multirow{4}{*}{ Polyethylene } & 6.3 & 1.4 & 65 & 0.023 & 0.056 & 0.088 & 0.153 \\
\hline & 7.1 & 1.5 & 65 & 0.028 & 0.068 & 0.110 & 0.165 \\
\hline & 8.3 & 1.8 & 50 & 0.114 & 0.184 & 0.296 & 0.428 \\
\hline & 10 & 2.2 & 50 & 0.210 & 0.385 & 0.495 & 0.701 \\
\hline \multirow{2}{*}{ Polyurethane } & 10 & 2.0 & 50 & 0.094 & 0.182 & 0.300 & 0.450 \\
\hline & 12 & 2.7 & 50 & 0.256 & 0.456 & 0.769 & 1.110 \\
\hline \multirow{2}{*}{$\begin{array}{l}\text { Polyvinyl- } \\
\text { chloride(PVC) }\end{array}$} & 10 & 2.2 & 60 & 0.111 & 0.250 & 0.410 & 0.620 \\
\hline & 10 & 2.2 & 50 & 0.153 & 0.333 & 0.500 & 0.800 \\
\hline \multirow{2}{*}{$\begin{array}{l}\text { Silicon } \\
\text { elastomer }\end{array}$} & 16 & 2.8 & 65 & 0.294 & 0.549 & 0.694 & 1.000 \\
\hline & 16 & 2.8 & 50 & 0.310 & 0.595 & 0.833 & 1.330 \\
\hline \multirow{2}{*}{ Teflon } & 12 & 3.0 & 65 & 0.303 & 0.400 & 0.690 & 0.952 \\
\hline & & 3.0 & 31 & 1.300 & 1.540 & 2.000 & 2.500 \\
\hline
\end{tabular}

Table 1. Measured flow rates through selected drainage catheters under specified pressure differences

Effective length of catheter is the distance from catheter hub to first side hole, 1 French $=1 / 3 \mathrm{~mm}$

and eventually result in PTBD failure. From this point of view, attention should paid to design and fluid mechanics of catheter in PTBD.

Presently, investigations into design and fluid mechanis of catheter in PTBD are lack. Kerlan et al, ${ }^{15}$ in the first time, measured bile flow rates through a series of different catheters at various pressure differences across the catheters in vitro, but their raw data remained unprocessed. Bret et al, ${ }^{16}$ clinically applied large size silicone catheters with 12, 15, 18 French outer diameters $(1 \mathrm{~mm}=3$ French), 2, 3, $4 \mathrm{~mm}$ inner diameters and $3 \times 5,4 \times 7,5 \mathrm{~mm} \times 9 \mathrm{~mm}$ side holes into 30 patients with obstructive jaundice due to stenoses and tumours in bile ducts for a long-term. It was shown that PTBD was effective in treating benign and mailignant bile duct strictures for a long-term, but frequently minor problems, mostly catheter-related, did persist. $^{17}$

A few in vitro experiments on fluid flow in percutaneous drainage catheters have been made by measuring drainage time at various catheter sizes and fluid viscosities. ${ }^{18}$ It was demonstared that a more viscous fluid required more large catheter to secure a rapid drainage. The flow rates of commerical multipurpose pigtail drainage catheters were measured in vitro at $30 \mathrm{mmHg}$ presssure difference. Since their inner diamter sizes were compariable, their flow rates were simliar in values. ${ }^{19}$ The effects of number and location of drainage catheter side holes on liquid flow rate were measured in vitro by emplying unilateral and bilateral side hole models, the catheters with bilateal side holes had a higer flow rate than those with unilateral side holes, adding more side holes could not improve flow rate once the number of the holes beyond a critical number of holes. ${ }^{20}$

The flow rates of simulated bile such as water, three additional water solutions of guar gum (four dynamic viscosities) through three kinds of pigtail cathetes (two multipurpose drainage catheters, one bilary drainage catherter) were measured in vitro at $12 \mathrm{cmH}_{2} \mathrm{O}$ pressure difference under side hole unobstructed and 


\begin{tabular}{|r|r|r|r|r|r|}
\hline \multicolumn{2}{|c|}{ Catheter } & \multicolumn{4}{|c|}{ Bile } \\
\hline $\begin{array}{c}\mathrm{d} \\
(\mathrm{mm})\end{array}$ & $\begin{array}{c}\mathrm{L} \\
(\mathrm{cm})\end{array}$ & $\begin{array}{c}\rho \\
(\mathrm{kg} / \mathrm{m} 3)\end{array}$ & $\begin{array}{c}\mu \\
(\text { Poise })\end{array}$ & $\begin{array}{c}v \\
\left(\mathrm{~mm}^{2} / \mathrm{s}\right)\end{array}$ & $\begin{array}{c}\Delta p \\
\left(\mathrm{cmH}_{2} \mathrm{O}\right)\end{array}$ \\
\hline 1.4 & 50 & 1000 & $0.01,0.02$ & 1,2 & $11.8-18.4$ \\
\hline 1.8 & 50 & 1000 & $0.01,0.02$ & 1,2 & $11.8-18.4$ \\
\hline 2.2 & 50 & 1000 & $0.01,0.02$ & 1,2 & $11.8-18.4$ \\
\hline 2.7 & 50 & 1000 & $0.01,0.02$ & 1,2 & $11.8-18.4$ \\
\hline
\end{tabular}

Table 2. The known parameters for a clinical application

obstructed conditions, and it was identified that the number of side holes did not affect in vitro biliary catheter drainage. ${ }^{21}$ The influence of catheter connections of catheter drainage flow rate was identified in vitro experimentally, it was shown that flow rates could be decreased significantly by connections, especailly when the inner diamater of a connection was smaller than the inner diameter of the catheters connected. ${ }^{22}$

A method was proposed to predict the clogging effect drainage catheters based on in vivo rabbit experiments by monitoring intra-catheter pressure. ${ }^{23}$ The commerical catheter for PTBD was ligated with a nylon thread just proximal to the first side hole to pervent the catheter obstruction caused from jejunobiliary reflux of the intestinal contents in internal PTBD. ${ }^{24}$ Fracture of the PTBD catheter could occure and cause bile peritonitis. ${ }^{25}$ Three new techniques were developed to retrieve fractured and intrahepatically dislodged PTBD catheters. ${ }^{26}$

Based on existing results on PTBD catheters mentioned above, bile fluid mechanics associated with clinical performance of catheters has been documented a little so far, and there are no empirical relationships for bile flow through biliary drainage catheters to assess their clinical performance in the literature currently. In the paper, the raw experimental data of a series of catheters on bile flow rate and pressure difference were analysed based on the elements of fluid mechanics to make the dead experimental data alive. An equivalent friction factor through the catheters was proposed and determined by using these observed data. An empirical relationship of bile flow rate through a catheter was estabilshed accordingly and applied to predict the bile flow rates through the catheters with various inner diameters under measured normal and abnormal biliary pressures and two bile viscosities in a common bile duct. The effects of catheter inner diameter and bile viscosity were clarified. The work can be meaningful to catheter fluid mechanics in biomedical/biomechanical engineering and clinical practice in PTBD procedure.

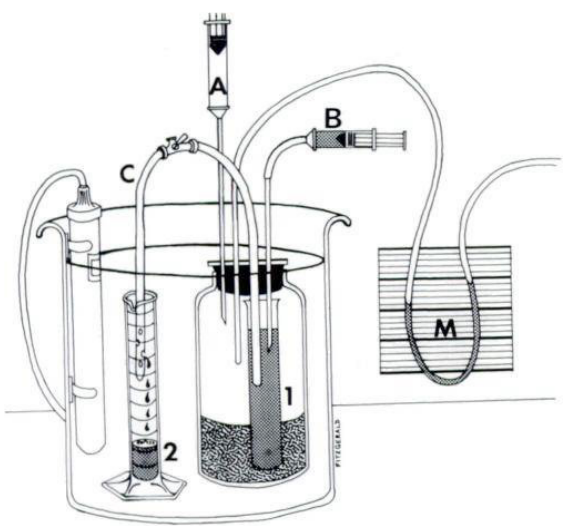

Figure 3. The experimental set-up for bile flow measurement through catheter in Kerlan et al. ${ }^{15}$ A bile stream is established in the catheter segment $\mathrm{C}$ by the pressure difference from chamber 1 to chamber 2 when the bile is at $37^{\circ} \mathrm{C}$ temperature 


\section{Experimental data}

Catheters for PTBD are a flexile, plastic central-hollowed tube with taping head and side holes as shown Figure $3 a$. In vitro bile flow meansuremts through the catheters have been very rare in the literature so far. At the moment, just one relatively complete data set for such flow measurement was identified in Kerlan et al. ${ }^{15}$ The experimental set-up in the mesurements is illustarted in Figure 3b. A catheter $(\mathrm{C})$ connects chamber 1 and chamber 2. Chamber 1 is pressurised and depressurised by adding and removing air with syringe $\mathrm{A}$ to maintain a constant pressure difference across the catheter and estabilsh a bile flow in it. This pressure difference is measured by using U-tube manometer (M). Bile level is held to be contant with syringe A by infusing bile. All chambers are submerged in a water bath to allow bile temperautre to be at $37^{\circ} \mathrm{C}$.

Freshly aspirated human hepatic bile with a dynamic viscosity of 0.01 Poise (0.001 Pass) and a density of $1000 \mathrm{~kg} / \mathrm{m}^{3}$ serves as experimental fluid. ${ }^{15}$ The experimental pressure differences, catheter sample lengths and diameters and measured bile flow rates are listed in Table $1 .{ }^{15}$

These raw exprimental data are going to be utilised to estabilish an empirical relationship between flow resistance factor/equivalent friction factor and Reynolds number and a correlation between bile flow rate and pressure gradient.

\section{Empirical relationships}

\section{Equivalent friction factor}

The hydraulic losses in the catheter shown in Figure $3 b$ include the friction loss over the wet surface, the incidence loss at the inlet of catheter, the secondary flow loss in the $180^{\circ}$ bend, and the diffusion loss across the side holes. At first, these losses are supposed to contribute an equivalent friction factor to simplify the problem; then, according to the skin friction factor formula for ducts, ${ }^{27}$ the equivalent friction factor will be calculated based on a known pressure difference, bile flow rate, effective length of the catheter and inner diameter of the catheter in the following manner

$$
\lambda=\frac{\Delta p}{\frac{V^{2}}{2 g} \frac{L}{d}}
$$

where is the gravity acceleration, $g=9.81 \mathrm{~m} / \mathrm{s}^{2}$, $V$ is the mean bile flow velocity. Because of $V=Q /\left(\pi d^{2} / 4\right)^{27}, E q$. (1) can be rewritten as

$$
\lambda=\frac{g \pi^{2} d^{5}}{8 Q^{2}} \frac{\Delta p}{L}
$$

As a result, the corresponding $\lambda$ - $\mathrm{Re}$ scattered data points based on the experimental data in Table 1 is present in Figure 4, where

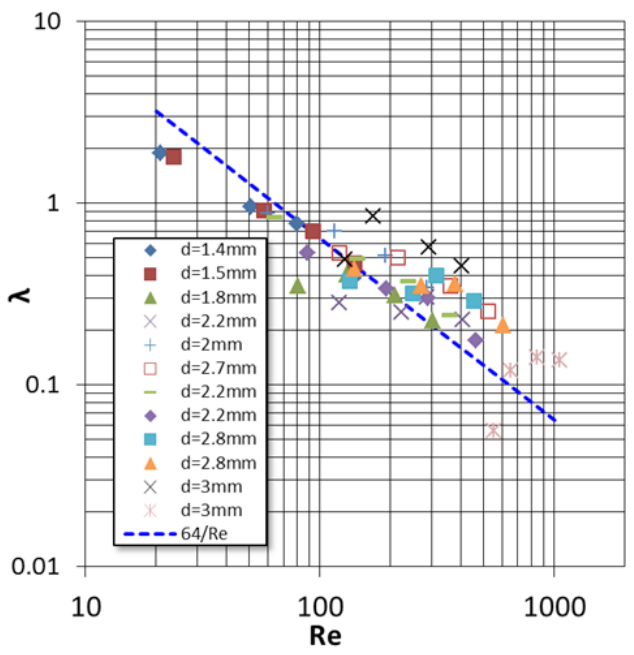

Figure 4. The scattered equivalent friction factors based on the experimental data in Table 1 and the analytical friction factor are plotted as a function Reynolds number 


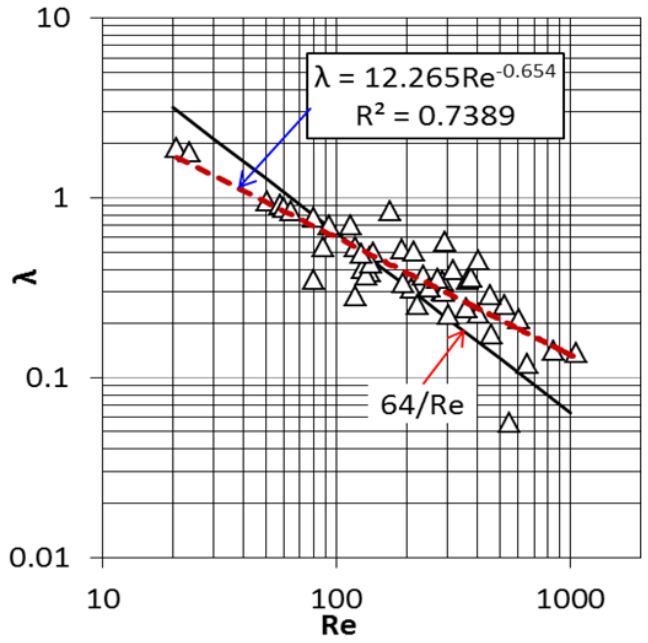

Figure 5. The fitted empirical correlation of equivalent friction factor in terms of Reynolds number and its comparison with the analytical friction factor for a catheter, the scattered data points are the same as those in Figure 4, the inner diameter is no longer indicated

$\operatorname{Re}=4 Q / \pi d v, \quad$ is the bile kinematic viscosity, $v=1 \mathrm{~mm} / \mathrm{s}^{2}{ }^{15}$ Because of $\operatorname{Re} \leq 1000$, the bile flow in the experimental catheters was in laminar regime. For comparison, the analytical friction factor for the fully developed laminar flow in a circular pipe in ${ }^{27}$ is plotted, too.

In the figure, some experimental points are below the $64 / \operatorname{Re}$ curve as $\operatorname{Re} \leq 200$, and some points are above the curve, suggesting the experimental shares a different slope with the analytical friction factor curve. The experimental has been best fitted by a power function of , the empirical formula is read as

$$
\lambda=\frac{12.265}{\operatorname{Re}^{0.6540}}, R^{2}=0.7389
$$

where is the correlation coefficient. A comparison of the experimental with the fitted curve is made in Figure 5.
The relationship of bile flow rate to pressure gradient

An empirical correlation for $\lambda$ has been established by Eq. (3) based on fluid mechanics method, the $\lambda$ expression is involved into $E q$. (2), and following equation is achieved

$$
\frac{12.265}{\operatorname{Re}^{0.6540}}=\frac{g \pi^{2} d^{5}}{8 Q^{2}} \frac{\Delta p}{L}
$$

Putting the Reynolds number $\operatorname{Re}=4 Q / \pi d v$ into Eq. (4), and the following equation is established

$$
\frac{12.265}{\left(\frac{4 Q}{\pi d v}\right)^{0.6540}}=\frac{g \pi^{2} d^{5}}{8 Q^{2}}\left(\frac{\Delta p}{L}\right)
$$

From Eq. (5), the bile flow rate through a catheter with the length driven by a pressure gradient can be solved and expressed by

$$
Q=\frac{8.3186 g^{0.7429} \pi d^{3.2288}}{128 v^{0.4859}}\left(\frac{\Delta p}{L}\right)^{0.74}
$$

where the units of $Q, d, L, \Delta p$ and $v$ are $\mathrm{m}^{3} / \mathrm{s}$, $\mathrm{m}, \mathrm{m}, \mathrm{mH} 2 \mathrm{O}, \mathrm{kg} / \mathrm{m}^{3}, \mathrm{~m}^{2} / \mathrm{s}$, respectively. In the equation, $Q \propto d^{3.2} v^{-0.49}(\Delta p / L)^{0.74}$ is held approximately.

For the fully developed laminar flow in a catheter, the friction factor is expressed analytically by $\lambda=64 / \operatorname{Re} .^{27}$ Involving the Reynolds number $\operatorname{Re}=4 Q / \pi d v$ into Eq. (2), an analytical relationship between bile flow rate and pressure gradient is worked out

$$
\frac{12.265}{\operatorname{Re}^{0.6540}}=\frac{g \pi^{2} d^{5}}{8 Q^{2}} \frac{\Delta p}{L}
$$

where the dynamic viscosity $\mu$ is related to the kinematic viscosity with $\mu=\rho v, \rho$ is the bile density, the unit of $\Delta p$ is $\mathrm{mH}_{2} \mathrm{O}$. In these 
expressions, $Q \propto d^{4} v^{-1}(\Delta p / L)^{1}$, suggesting parameters $d, v$ and $\Delta p / L$ exhibit a stronger effect on $Q$ in comparison with those in $E q$. (6) originated from experimental observations.

\section{Another sort of relation between bile flow rate and pressure gradient}

In the relationship of bile flow rate to pressure gradient section, an empirical friction factor is determined first, then it replaces the $\lambda$ in Eq. (2), and Re is experienced in terms of bile rate; finally, a relationship between bile flow rate and pressure gradient is sought as expressed with Eq. (6). In fact, we can derive an empirical relationship between bile flow rate and pressure gradient directly based on analytical Eq. (7). This method has used in the determination of an empirical expression between bile flow rate and pressure gradient across animal biliary tree in vitro in. ${ }^{28}$ This method will be tried on the experimental data on the catheters ${ }^{15}$ here.

A few perfusion experiments were performed on the biliary tree (hepatic, cystic and common bile ducts) of six fasting mongrel $\operatorname{dogs}^{28}$ by using saline and bovine bile at different bile perfusion flow rates, respectively. The pressure differences across the tree were recorded. It was identified that the experimental scattered points of $(\Delta p / L$,$) and (\rho g \Delta p / L$, $128 \mu Q / \pi d^{4}$ ) can be best fitted with a linear relationship in a log-log plot. Then the bile flow rate can be obtained in terms of pressure gradient, like Eq. (7).

In doing so, the experimental data points of $\Delta p / L-128 v Q / \pi g d^{4}$ and $\rho g \Delta p / L$ -are plotted and fitted, respectively, for the experimental data in the catheters in [15]. The experimental scattered data points and the corresponding regression formulas are illustrated in Figure 6. Based on these formulas, the bile flow rate through a catheter under a known pressure gradient is given by

$$
\begin{gathered}
Q=\frac{0.3234 \pi g d^{4}}{128 v}\left(\frac{\Delta p}{L}\right)^{0.6458} \\
Q=\frac{8.573 \pi d^{4}}{128 \mu}\left(\frac{\rho g \Delta p}{L}\right)^{0.6458}, R^{2}=0.7487
\end{gathered}
$$

where the units of $Q, d, L, \Delta p, \rho, v$ and $\mu$ are $\mathrm{m} 3 / \mathrm{s}, \mathrm{m}, \mathrm{m}, \mathrm{mH} 2 \mathrm{O}, \mathrm{kg} / \mathrm{m} 3, \mathrm{~m} 2 / \mathrm{s}, \mathrm{Pa} . \mathrm{s}$, respectively.
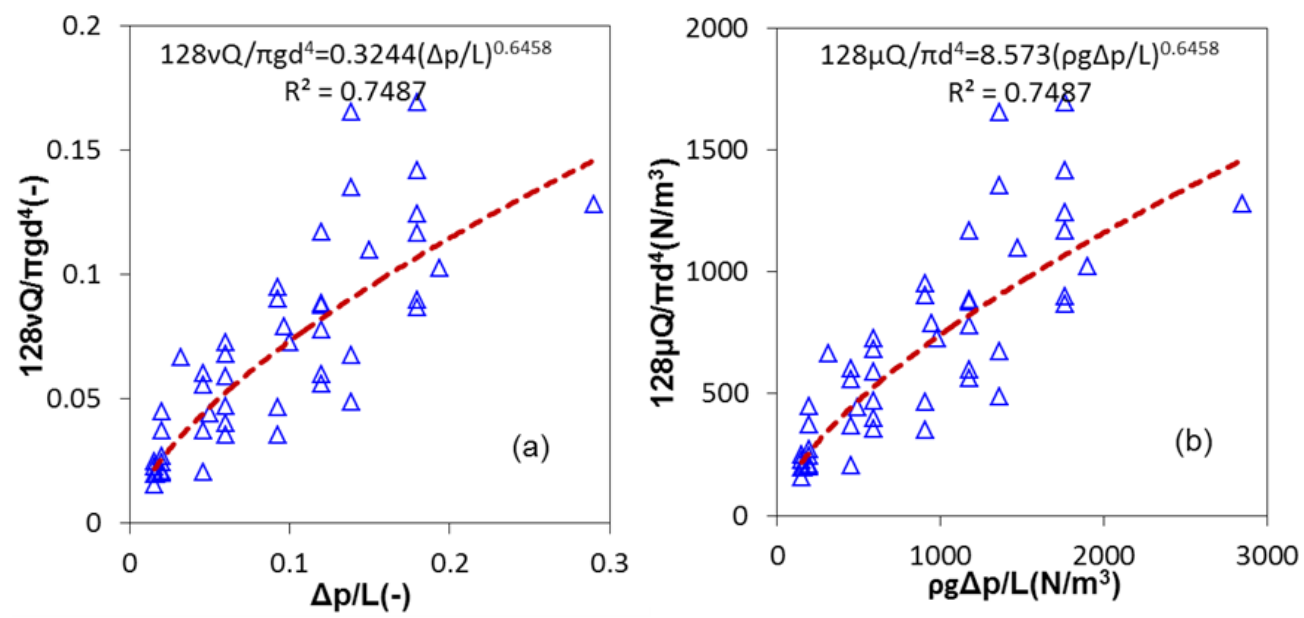

Figure 6. The scattered data points of ( $\left.\Delta p / L, 128 v Q / \pi g d^{4}\right)$ and $\left(\rho g \Delta p / L, 128 \mu Q / \pi d^{4}\right)$ as well as the corresponding regression formulas, the scattered data points are the same as those in Figure 4, the inner diameter is no longer indicated 


\section{A comparison of two kinds of relationship}

From the same set of experimental data, two relationships have been obtained for bile flow rate in terms of pressure gradient across a catheter expressed by Eq. (6) and (8). Two relationships may result in a different bile flow rate under the same clinical condition. To confirm this effect, a computational example is provided here.
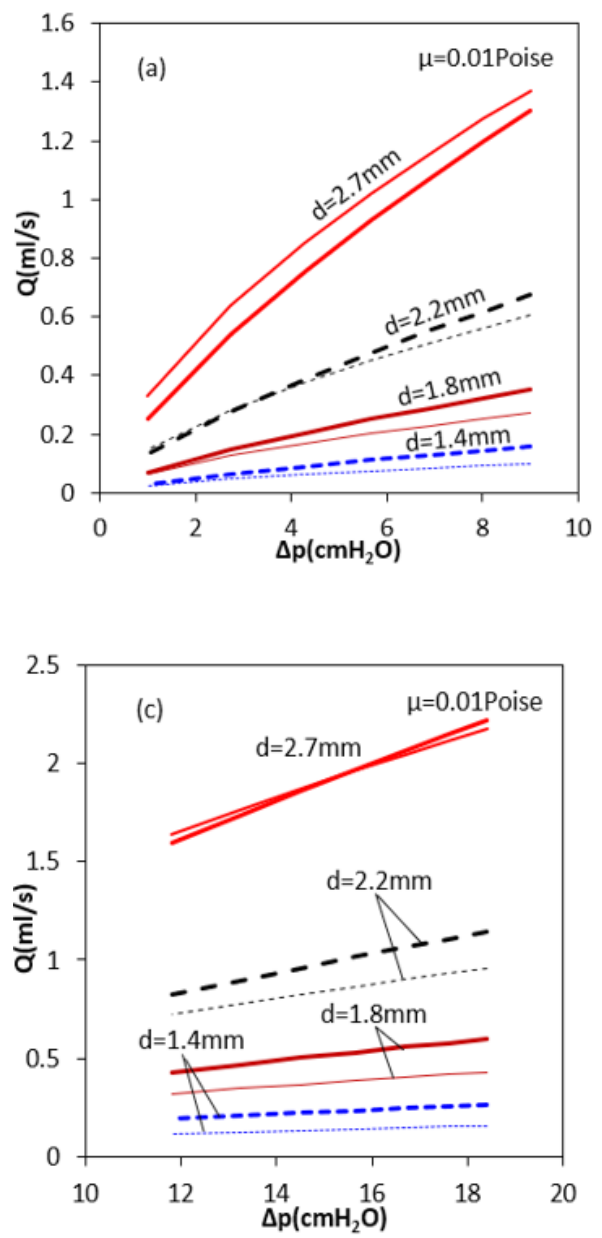

The biliary mean resting pressure in normal human common bile duct is $11.8 \mathrm{cmH}_{2} \mathrm{O}$, but in the duct with obstructive jaundice, it is $18.4 \mathrm{cmH}_{2} \mathrm{O}^{29,30}$ It is assumed that a $50 \mathrm{~cm}$ long catheter is connected to a common bile duct with obstructive jaundice at the $184 \mathrm{cmH}_{2} \mathrm{O}$ initial pressure, after drainage persists for a certain long of time, the biliary pressure restores to the normal level of $11.8 \mathrm{cmH}_{2} \mathrm{O}$. This means that the pressure difference across the
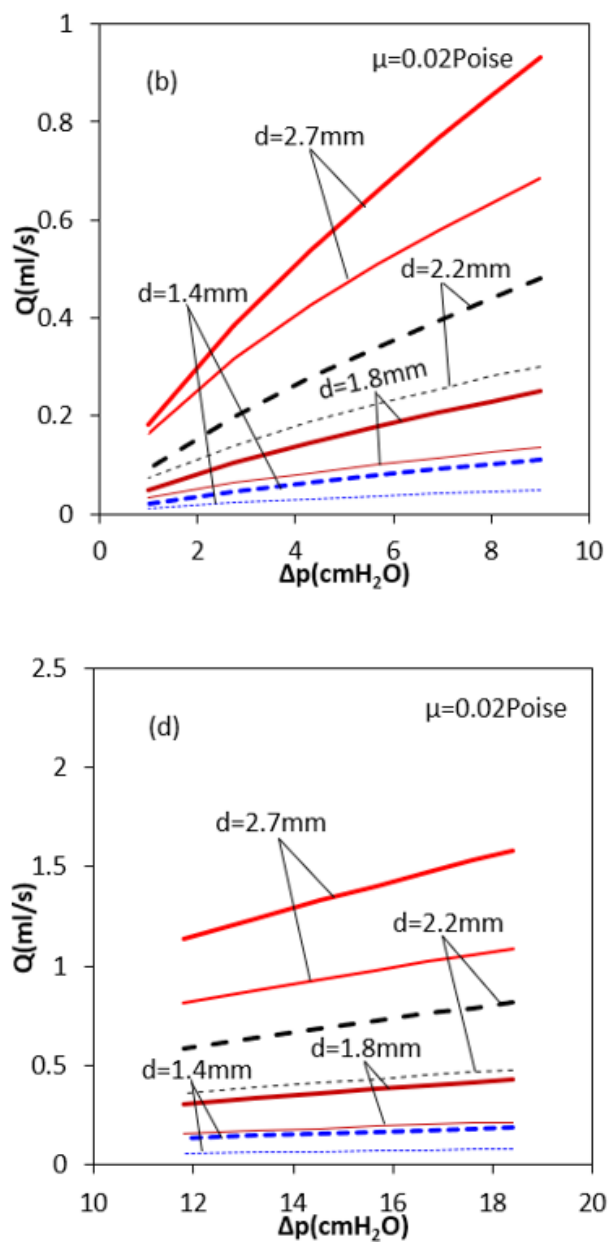

Figure 7. The predicted bile flow rate through four catheters in terms of bile pressure difference across the catheters at two viscosities, the thick lines are for Eq. (6), but the thin lines for Eq. (8); in (a) and (b), the pressure difference is the range of the experiments in Table 1; while in $(c)$ and $(d)$, the pressure difference is based on clinical observation ${ }^{29,30}$ 
catheter varies to $11.8 \mathrm{cmH}_{2} \mathrm{O}$ from $184 \mathrm{cmH}_{2} \mathrm{O}$. The bile dynamic viscosity is 0.01 Poise 15 and 0.02 Poise 31 with a density of $1000 \mathrm{~kg} / \mathrm{m} 3$. The catheter inner diameters are $d=1.4,1.8,2.2$ and $2.7 \mathrm{~mm}$, respectively, based on Table 1. These known parameters are summarised in Table 2.

Firstly, Eq. (6) and (8) are used to predict the bile flow rates under the experimental conditions such as 1, 2, $69 \mathrm{cmH}_{2} \mathrm{O}$ pressure differences and 0.01 Poise viscosity as shown in Table 1 and at four inner diameters in Table 2. The two equations result in nearly the same bile flow rate profiles as shown in Figure 7a. This is not surprised because they have originated from the same experimental data set and applied under nearly the same condition in terms of pressure difference, viscosity and catheter inner diameter as in the experiments. ${ }^{15}$

Secondly, two equations are employed to estimate the bile flow rates at 0.02 Poise viscosity, while the rest condition remain the same as those for Figure 7a. In the experiments of ${ }^{15}$ the tested liquid viscosity was kept being 0.01 Poise. The prediction at 0.02 Poise viscosity is an extrapolation from the results at 0.01 Poise viscosity. The flow rates from Eq. (6) are larger than those from Eq. (8), as demonstrated in Figure $7 \mathrm{~b}$ because of $Q \propto v^{-0.49}$ in Eq. (6) rather than $Q \propto v^{-1}$ in Eq. (8). These suggest that the flow rates predicted with two equations at a viscosity more than 0.01 Poise are not accurate as those at 0.01 Poise.

Finally, two equations are utilized to calculate $Q-\Delta p$ curves at four inner diameters and two viscosities in Table 2 and under the pressure differences higher than those in Table 1. The predicted $Q-\Delta p$ curves are illustrated in Figure $7 c$ and $d$. These predictions are extrapolation from an experimental pressure difference in ${ }^{15}$ to a higher-pressure difference in clinical observation. Once again two equations lead to a very similar flow rate curve at to 0.01
Poise viscosity, but a very different curve at 0.02 Poise viscosity.

Clearly, the bile flow rate rises with both increasing pressure difference and inner diameter but reduces with increasing viscosity. The effect of inner diameter on the flow rate is the most significant in comparison with that of the other factors. To secure a relatively high bile flow rate and better drainage, a catheter should prefer an inner diameter as big as possible, especially for thick bile.

From Figure $7 c$ and $d$, since the bile flow rate is inversely proportional to the viscosity in Eq. (8), the viscosity in Eq. (8) exhibits a stronger effect on the flow rate than the viscosity does in Eq. (6). As a result, the flow rates predicted with $E q$. (8) are smaller than those with $E q$. (6) in most cases. In the case of $d=2.7 \mathrm{~mm}$ and $\mu=0.01$ Poise, two equations result in nearly the same flow rate. This is because of the dominated effect of inner diameter on the flow rate.

In the experiments in [15], the fluid viscosity was kept constant. Thus, there is no effect of fluid viscosity reflected both Eq. (6) and (8). If the viscosity varied in the experiments in, ${ }^{15}$ Eq. (6) and (8) should lead to a nearly identical bile flow under the same clinical condition. To validate two empirical relationships of Eq. (6) and (8), more experimental data on in vitro bile flow measurements in catheters are desirable with more viscous liquids and under pressure differences higher than $9 \mathrm{cmH}_{2} \mathrm{O}$.

\section{Discussions}

In the paper, a set of raw experimental data on in vitro bile flow through a series of catheter samples in ${ }^{15}$ was analysed in fluid mechanics context. An empirical equivalent friction factor was figured out and the corresponding flow rate formula of bile through a catheter was 


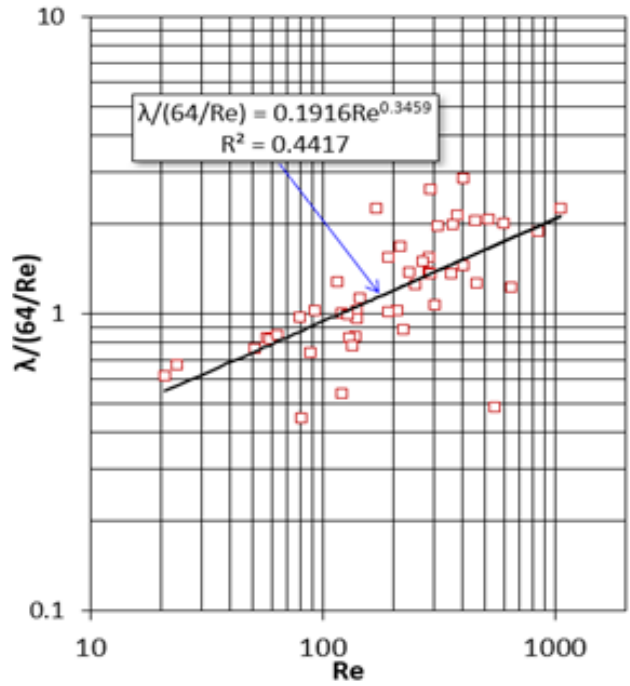

Figure 8. The ratio of the equivalent friction factor to the theoretical friction factor of the fully developed laminar flow in a circular pipe, i.e. as a function of Reynolds number, the scattered data points are the same as those in Figure 4, the inner diameter is no longer indicated.

established. Finally, an application example was demonstrated and the effects of catheter inner diameter, pressure difference and bile viscosity were clarified. Such a study has not been found in literature so far. The study in the paper has contributed to the elements of fluid mechanics of catheter in PTBD.

In the equivalent friction factor, there are minor hydraulic losses, namely entry loss at the catheter inlet, secondary flow loss in the bend of a catheter, and diffusion loss through the side holes in the catheter. It is not easily to measure and estimate these minor losses. Here using the ratio of the equivalent friction factor to the theoretical friction factor for the fully developed laminar flow in a circular pipe, i.e. $\lambda /(64 / \mathrm{Re})$ is used to estimate these minor losses. As a result, the scattered data points and a regression equation are illustrated in Figure 8. Clearly, ratio augments with increasing Re, particularly, if $\operatorname{Re}>100$, then $\lambda /(64 / \operatorname{Re})>1$, indicating the dominant minor losses. When $\operatorname{Re}<100$, the ratio is less than one. This effect may be due to some errors in the experiments or the thickening effect of non-Newtonian bile at low flow rate.

Note that, in clinical practice, the bile flows into the side holes of a catheter rather than out of the holes as shown in the experiments as shown in Figure 3. The diffusion loss in two scenarios may be different each other. This issue needs to be confirmed experimentally in the future. CFD studies on the minor hydraulic losses in biliary drainage catheters are also worthy of being attempted.

Recently, the flow rates in three commerical multipurpose pigtail drainage catheters at 30 $\mathrm{mmHg}$ presssure difference were measured in vitro with water by Macha, Thomas and Nelson in $2006{ }^{19}$ The flow rates of water, three water solutions of guar gum across three pigtail

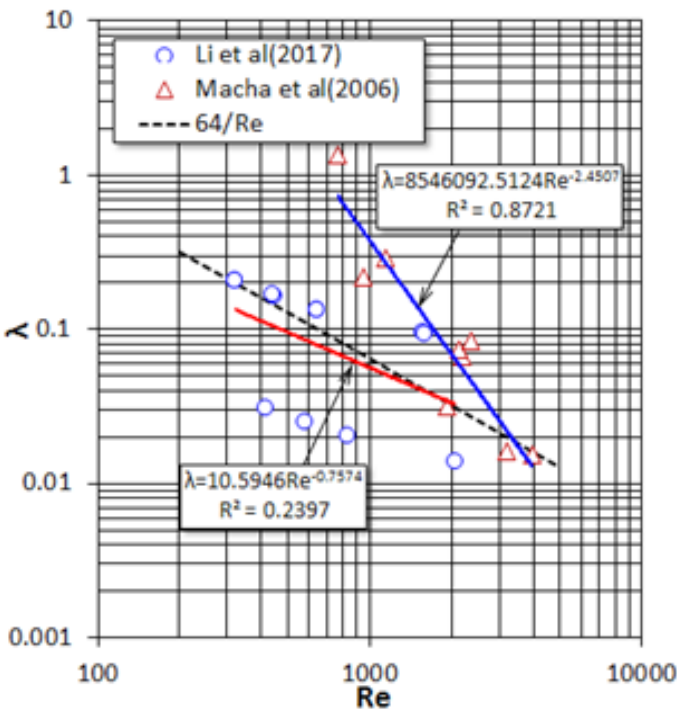

Figure 9. The experimental equivalent friction factors respectively by Macha, Thomas and Nelson ${ }^{19}$ and Li, Ballard and D'Agostino ${ }^{21}$ and fitted empirical correction of in terms of Reynolds number and its comparison with the analytical friction factor for a catheter. 
cathetes (two multipurpose drainage catheters, one biliary drainage catherter) were in vitro measured at $12 \mathrm{cmH}_{2} \mathrm{O}$ pressure difference under side hole unobstructed and obstructed conditions, and it was identified that the number of side holes don't affect in vitro bilary catheter drainage. ${ }^{21}$ The catheter geometrical parameters were presented in ${ }^{19}$ and ${ }^{21}$. The flow rates in Figure 4 in ${ }^{19}$ and Figure 2 in 21 for the unobstructed catheters were read and the equivalent frictiom factors were calculated by them with Eq. (2), and the results are illustrated in Figure 9.

Clearly, the data points in two experiments are quite few and the Reynolds number is in the range of $300-4000$, which is higher than that (20-1000) in Figure 4. The factors from the experimental data in ${ }^{19}$ exhibit siginifcant variation. Even though the resgrssion equation for them is sightly below the analytical curve of $64 / \mathrm{Re}$, its correlation coefficent is as small as 0.24 .

The friction factors from the experimental data in ${ }^{21}$ are considerably higher than the analytical curve as $\operatorname{Re} \leq 2000$. Nonetheless further experimental comfirmation is on demand.

Since there is one viscosity in the experiments and no information about the used bile rheology in ${ }^{15}$, the bile in fluid mechanics model is considered Newtonian. Ooi et al measured the bile dynamic viscosity and found that the bile rheology of 20 out of 59 patients is Newtonian. ${ }^{32}$ Reinhart, Naf and Werth found the bile of the majority samples from the common bile duct of 138 patients $(64.5 \%)$ are Newtonian. ${ }^{33}$ These facts suggest that the Newtonian bile model seems to be reasonable. In some cases, however, the bile can be non-Newtonian, $32-35$ therefore the correlation needs be updated in the future based on in vitro experimental data on non-Newtonian fluid flow through PTBD catheters.

The bile viscosity can vary significantly across patients, for example, the dynamic viscosity of gallbladder bile is 0.0177-0.08 Poise $^{32}$, and even higher in gallbladder bile of patients with cholesterol (0.05 Poise) and mixed stones (0.035 Poise) compared to hepatic bile (0.02 Poise) [31]. Therefore, more in vitro studies on bile flow through a catheter with a variety of viscosities need to be launched in the future.

\section{Conculisons}

Based on a set of existing in vitro bile flow measurements through the catheters made with five kinds of material and in various inner diameters and lengths for PTBD application under different pressure differences across the catheters, an equivalent friction factor was put forwarded and determined. Furthermore, an empirical correlation of bile flow rate through a catheter to pressure gradient, inner diameter and bile viscosity was developed and applied to clarify effects of variable catheter inner diameter and bile viscosity under the physiological bile pressure differences in obstructed common bile ducts. The effect of minor hydraulic losses in the catheters was identified. It was shown that the proposed equivalent friction factor was proportional to Reynolds number in a power of -0.654 rather than -1 for the fully developed limner flow in circular pipes. The bile flow rate through a catheter was proportional to inner diameter, kinematic viscosity, and pressure gradient in the powers of $3.2,-0.5$ and 0.74 , respectively. The minor hydraulic losses could be dominant as Reynolds number was higher than 100. Further work includes in vitro bile flow measurements at different viscosities, non-Newtonian bile effect on bile flow rate through a catheter and minor hydraulic losses estimation in biliary drainage catheters based CFD simulations. 


\section{Compliance with Ethical Standards}

Funding: This study was not funded by any organizations.

Conflict of interest: The author has no conflict of interest.

Ethical approval: This article does not contain any studies with human participants or animals performed by the author.

\section{REFERENCES}

1. Hoevels J, Lunderquist A, Ihse I. Percutaneous transhepatic intubation of bile ducts for combined internal-external drainage in preoperative and palliative treatment of obstructive jaundice. Gastrointestinal Radiology, 1978,3: 23-31.

2. Ring EJ, Husted JW, Oleaga JA, Freiman DB. A multihole catheter for maintaining longterm percutaneous antegrade biliary drainage. Radiology, 1979,132:752-754.

3. Nakayama T, Ikeda A, Okuda K. Percutaneous transhepatic intubation of biliary tract. Gastroenterology, 1978,74(3):554-558.

4. Ferrucci JT, Mueller PR, Harbin WP. Percutaneous transhepatic biliary drainage. Diagnostic Radiology, 1980,135:1-13.

5. Mueller PR, van Sonnenberg E, Ferrucci J. Percutaneous biliary drainage: technical and catheter-related problems in 200 procedures. American Journal of Roentgenology, 1982,138:17-23.

6. Mendez G, Russsell E, LePage JR, Guerra JR, Posniak $R A$, Trefler $M$. Abandonment of endoprosthetic drainage technique in malignant biliary obstruction. American Journal of Roentgenology. 1984,143:617-622.

7. Hamlin JA, Friedman $M$, Stein $M G$, Bray JF. Percutaneous biliary drainage: complications of 118 consecutive catheterizations. Radiology, 1986,158:199-202.

8. Joseph P, Bizer LS, Sprayregen SS, Gliedman ML. Percutaneous transhepatic biliary drainage. JAMA, 1986,255:2763-2767.

9. Sirinek $K R$, Levine BA. Percutaneous transhepatic cholangiography and biliary drainage. Archives of Surgery, 1989,124:885-888.

10. Weber A, Gaa J, Rosca B, Born P, Neu B, Schmid
RM, Prinz C. Complications of percutaneous transhepatic biliary drainage in patients with dilated and nondilated intrahepatic ducts. European Journal of Radiology, 2009,72:412-417.

11. Knap D, Orlecka N, Judka R, et al. Biliary duct obstruction treatment with aid of percutaneous transhepatic biliary drainage. Alexandria Journal of Medicine, 2016,52:185-191.

12. Clark RA, Mitchell SE, Colley DP, Alexander E. Percutaneous catheter biliary decompression. American Journal of Roentgenology, 1981,137:503-509.

13. Yee CAN, Ho CS. Complications of percutaneous biliary drainage: benign vs malignant diseases. American Journal of Roentgenology, 1987,148:1207-1209.

14. Carrasco CH, Zornoza J, Bechtel WJ. Malignant biliary obstruction: complications of percutaneous biliary drainage. Radiology, 1984,152:343-346.

15. Kerlan RK, Stimac G, Pogany AC, Ring EJ Bile flow through drainage catheters: an in vitro study. American Journal of Roentgenology, 1984,143:1085-1087.

16. Bret PM, Bretagnolle M, Fond A, Valette PJ, Bret P. Use of large silicone catheters in patients in longterm percutaneous transhepatic biliary drainage. Cardiovascular and Interventional Radiology, 1986,9:57-58.

17. Born P, Tripttrap A, Frimberger E, et al. Longterm results of percutaneous transhepatic biliary for benign and malignant bile duct strictures. Scandinavian Journal of Gastroenterology, 1998, 33(5): 544-549.

18. ParkJK, Kraus FC, Haaga JR. Fluid flow during percutaneous drainage procedures: An in vitro 
study of the effects of fluid viscosity, catheter size and adjunctive urokinase. American Journal of Roentgenology, 1993,160:165-169.

19. Macha DB, Thomas J, Nelson RC. Pigtail catheters used for percutaneous fluid drainage: comparison of performance characteristics. Vascular and Interventional Radiology, 2006, 238(3):1057-1063.

20. Ballard DH, Alexander JS, Weisman JA, Orchard MA, Williams JT, D'Agostino HB. Number and location of drainage catheter side holes: in vitro evaluation. Clinical Radiology, 2015,70:974-980.

21. Li AY, Ballard DH, D'Agostino HB. Biliary drainage catheters fluid dynamics: In vitro flow rates and patterns. Diagnostic and Interventional Imaging, 2017,98:355-358.

22. Ballard DH, Flanagah ST, Li H, D'Agostino HB. In vitro evaluation of percutaneous drainage catheters: Flow related to connections and liquid characteristics. Diagnostic and Interventional Imaging, 2018,99: 99-104.

23. Lee KH, Han JK, Kim KG, Byun Y, Yoon CJ, Kim SJ, Choi BI. Clogging of drainage catheters: Quantitative and longitudinal assessment by monitoring intracatheter pressure in catheters and rabbits. Radiology, 2003,227(3): 833-838.

24. Hamada T, Tsujino T, Isayama H, Hankuta R, Ito Y, Nakata R, Koike K. Percutaneous transhepatic biliary drainage using a ligated catheter for recurrent catheter obstruction: antireflux technique. Gut and Liver, 2013,7(2):255-257.

25. Nghiem DD. Bile leakage after fracture of percutaneous transhepatic biliary drainage catheters. JAMA, 1984,251(7):892.

26. Liu HT, Tseng HS, Lin YY, Liu CA. Percutaneous transhepatic techniques for retrieving fractured and intrahepatically dislodged percutaneous transhepatic biliary drainage cathe- ters. Diagnostic and Interventional Radiology, 2017,23:461-464.

27. White FM, Fluid Mechanics (7th edition), New York: McGraw-Hill Companies, Inc., 2011.

28. Rodkiewicz CzM, Otto WJ, Scott $G W$. Empirical relationships for the flow of bile. Journal of Biomechanics, 1979,12:411-413.

29. White TT, Waisman H, Hopton D, Kavlie H. Radiomanometry, flow rates, and cholangiography in the evaluation of common bile duct disease. American Journal of Surgery, 1972,123:73-79.

30. van Sonnenberg E, Ferrucci JT, Neff CC, Mueller $P R$, Simeone JF, Wittenberg J. Biliary Pressure: manometric and perfusion studies at percutaneous transhepatic cholangiography and percutaneous biliary drainage. Radiology, 1983,148:41-50.

31. Jungst D, Niemeyer A, Muller I, Zundt B, Meyer $G$, Wilhelmi M, del Pozo R. Mucin and phospholipids determine viscosity of gallbladder bile in patients with gallstones. World Journal Gastroenterology, 2001,7(2):203-207.

32. Ooi RC, Luo XY, Chin SB, Johnson AG, Bird NC. The flow of bile in the human cystic duct. Journal of Biomechanics, 2004,37 (12):1913-1922.

33. Reinhart WH, Naf G, Werth B. Viscosity of human bile sampled from the common bile duct. Clinical Hemorheology and Microcirculation, 2010,44(3):177-182.

34. Coene PPLO, Groen AK, Davids PHP, Hardeman $M$, Tytgat GNJ, Huibregtse $K$. Bile viscosity in patients with biliary drainage. Scandinavian Journal of Gastroenterology, 1994,29:757-763.

35. Kuchumov AG, Gilev V, Popov V, Samartsev V, Gavrilov V. Non-Newtonian flow of pathological bile in the biliary system: experimental investigation and CFD simulations. Korea-Australia Rheology Journal, 2014,26(1):81-90.

\section{Wenguang Li}

School of Energy and Power Engineering, Lanzhou University of Technology

Lanzhou, Gansu 730050, China

15810086985 


\section{ÍZÜLETEINK}

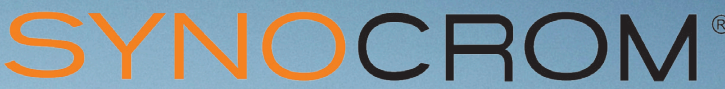

B IOENGINEERED HYALURONICACID

\section{VÉDELMÉRE}

\section{INTRAARTIKULÁRIS INJEKCIÓ}

A SYNOCROM ${ }^{\circledR}$ intraartikuláris készítményekkel nagymértékben csökkenthető azízületi fájdalom, és javítható az ízület mozgathatósága.

A SYNOCROM ${ }^{\circledR}$ termékek nagy tisztaságú, biofermentációs eljárással készült hyaluronsavat tartalmazó az ízületi folyadék pótlására alkalmazható injekciós kiszerelésű orvostechnikai eszközök. A termékek elsődlegesen a térdízületi arthrosis kezelésére szolgálnak, de egyéb ízületek degeneratív elváltozásai esetén is sikerrel alkalmazhatóak.

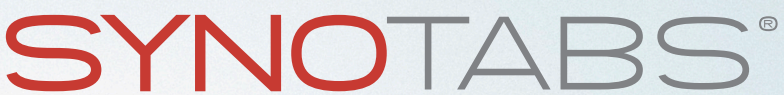

\section{PORCERŐSÍTŐ TÁPLÁLÉK KIEGÉSZíTŐ}

A SYNOTABS ${ }^{\circledR}$ filmtabletta

kiszerelésben kapható táplálék kiegészítő, amely az egészséges izületek és porcok fenntartásához járul hozzá. Speciális összetétele révén a SYNOTABS ${ }^{\circledR}$ filmtabletta tartalmaz minden olyan fontos összetevőt, ami segíti az ízületek védelmét.
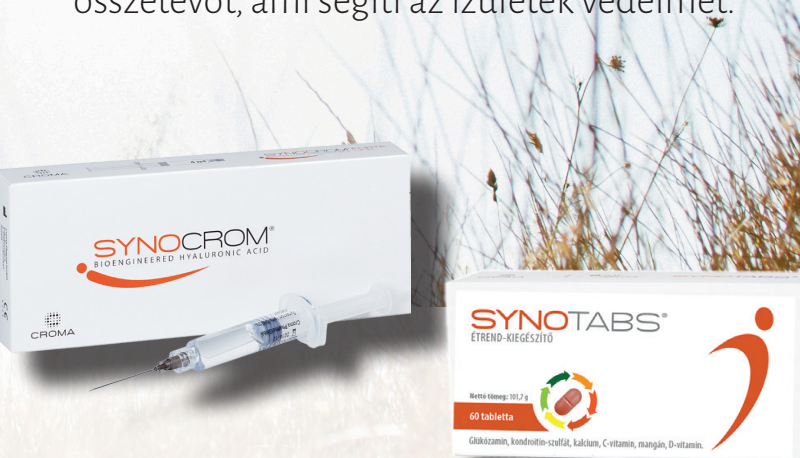